\title{
A Research on the Differences of Consumers on Socio-Demographic Characteristics: The Internet of Things (IoT) Smart Homes
}

\author{
Poh-ChuinTeo, Theresa C.F Ho, Rafidah Othman, BeniWidarmanYusKelana, Daniel Tie
}

\begin{abstract}
Due to the huge potential market demand and rapid technological growth as humans aspire to live in a seamless connected world, the Internet of Things (IoT) has emerged as one of the most popular research topics. Amongst all applications of IoT, Smart Homes has been developed in order to provide home automation, such as intelligent electronic devices and lighting, or voice control over the devices. However, despite a significant number of investments having been invested in its development, IoT Smart Homes is still not an influential threat to traditional conventional houses. Grounded by the Value-Based Adoption Model, this study focused on perceived benefits, perceived sacrifice, perceived value and adoption intention, and strived to examine the differences of individuals in Smart Homes adoption decision in the Malaysia context. Indeed, the sub-dimensions of perceived benefits, namely perceived usefulness, perceived enjoyment and perceived facilitating condition; and perceived sacrifice such as perceived privacy risk, perceived technicality, perceived innovation resistance and perceived fee, were also explored. In addition, due to the growing attention on environmental issues in the recent decades, environmental innovativeness and environmental concern were also studied. The result of analysis showed that individuals were significantly different based on their socio-demographic background. Implications of study were also discussed and recommendations were given based on the research findings.
\end{abstract}

Index Terms-Internet of Things, Smart Homes, Adoption Intention, Value-Based Adoption Model

\section{INTRODUCTION}

The industrial value creation in the early industrialised countries is currently shaped by the development towards the fourth stage of industrialization, which is also widely known as the Industry 4.0 that provides immense opportunities for realising sustainable manufacturing using the ubiquitous information and communication technology infrastructure [1]. Since then, the Internet of Things (IoT) has been one of the emerging topics in the recent decade.

The major technology companies are vastly investing into currently due to the great potential market demand and rapid

Revised Version Manuscript Received on September 14, 2019.

Poh-ChuinTeo, AzmanHashim International Business School, UniversitiTeknologi Malaysia, Malaysia (Email: pohchuin@utm.my)

Theresa C.F Ho, AzmanHashim International Business School, UniversitiTeknologi Malaysia, Malaysia (Email: hctheresa@utm.my)

Rafidah Othman, AzmanHashim International Business School, UniversitiTeknologi Malaysia, Malaysia (Email: rafidah.othman@utm.my)

BeniWidarmanYusKelana, AzmanHashim International Business School, UniversitiTeknologi Malaysia, Malaysia (Email: beni@utm.my)

Daniel Tie, Tunku Abdul Rahman University College, Kuala Lumpur, Malaysia (Email: danielts-wb09@ student.tarc.edu.my) technological growth as humans aspire to live in a seamless connected world. IoT refers to a network or interaction of multiple devices that are equipped with the essential sensors or software, in which these devices collect data from the physical world and exchange such information to create better combined user experience and other innovative service or functions out of its original function [2]. For example, a consumer could interact with the Smart TV to receive information on current weather or traffic condition, instead of just watching a television broadcast.

One of the applications of this technology is in the IoT Smart Homes, which is mostly developed into providing home automation, such as intelligent electronic devices and lighting, or voice control over the devices. IoT Smart Homes is widely considered as a revolutionary product that distinct itself from the traditional homes, even though it is still very new in the Malaysian market. [3] reported that developing economy like Malaysia is often slower in adapting into the IoT technology, despite the government tremendous effort in boosting the adaption of IoT services and IoT-led industry by introducing the National IoT Strategic Roadmap in 2014 [4].

However, despite a significant number of investments having been invested in its development, IoT Smart Homes is still not an influential threat to traditional conventional houses. Grounded by the Value-Based Adoption Model, this study focused on perceived benefits, perceived sacrifice, perceived value and adoption intention, and strived to examine the differences of individuals in Smart Homes adoption decision in the Malaysia context. Indeed the sub-dimensions of perceived benefits, namely perceived usefulness, perceived enjoyment and perceived facilitating condition; and perceived sacrifice such as perceived privacy risk, perceived technicality, perceived innovation resistance and perceived fee, were also explored. In addition, due to the growing attention on environmental issues in the recent decades, environmental innovativeness and environmental concern were also studied.

\section{LITERATURE REVIEW}

\section{Value-based Adoption Model}

A bundle of research has been done on consumer's purchase intention and decisions, including the antecedents and consequences.

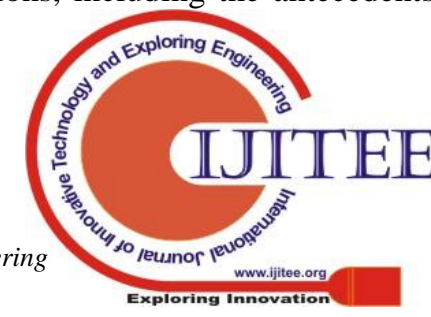




\section{A RESEARCH ON THE DIFFERENCES OF CONSUMERS ON SOCIO-DEMOGRAPHIC CHARACTERISTICS: THE INTERNET OF THINGS (IOT) SMART HOMES}

Theory of Reasoned Action and Theory of Planned Behaviour are deemed as popular theories that applied in this field of study. Indeed, for studies related to relatively new ideas and innovative products, researchers tend to employ Technology Acceptance Model (TAM). In recent years, TAM has been extended, and has led to the development of a newer model, namely Value-based Adoption Model (VAM) that introduced by [5]. The comparison of TAM and VAM is as presented in Table 1.

Table 1: Comparison of TAM and VAM

\begin{tabular}{|l|l|l|}
\hline Subject & $\begin{array}{l}|c| \\
\text { Individuals } \\
\text { (Employees in an } \\
\text { organizational } \\
\text { setting) }\end{array}$ & $\begin{array}{l}\text { TAM } \\
\text { (Technology user } \\
\text { and service } \\
\text { consumer) }\end{array}$ \\
\hline Environment & $\begin{array}{l}\text { Traditional } \\
\text { technologies } \\
\text { (e.g. spreadsheet, } \\
\text { word processor) } \\
\text { Features }\end{array}$ & $\begin{array}{l}\text { Und Communication } \\
\text { Technology (ICT) } \\
\text { (e.g. M-Internet, } \\
\text { for work purposes }\end{array}$ \\
& $\begin{array}{l}\text { Internet banking) } \\
\text { The cost of } \\
\text { mandatory adoption } \\
\text { ICT for personal } \\
\text { purposes }\end{array}$ \\
$\begin{array}{l}\text { Usage is borne by } \\
\text { the organisation }\end{array}$ & $\begin{array}{l}\text { The cost of } \\
\text { voluntary adoption } \\
\text { Usage is borne by } \\
\text { the individuals }\end{array}$ \\
\hline
\end{tabular}

Source: Adopted and adapted from [5].

VAM considers the value of chosen study object, by comparing the perceived benefit and perceived sacrifice, research results have proved that VAM is more effective than TAM in explaining customer adoption. The key variables that construct Value-based Adoption Model include perceived benefit, perceived sacrifice, perceived value and adoption intention. VAM would be able to capture the monetary sacrifice elements and show adoption as a comparison of benefits and cost [6]. This is because it is based on a cost-benefit paradigm that reflecting the decision making process whereby the decision to use is made by comparing the cost of uncertainty in deciding to adopt a new technology or product [7].

\section{Perceived Value and Behavioral Intention}

The primary assumption in the consumers' decisions making process is the desire for value maximisation, where value considers and reflects both benefit and loss [8]. This decision making process is based on a cost-benefit paradigm where consumers balance the benefit received and sacrifice made to evaluate the value of the product or services to them. Perceived value is derived based on consumers perceived preference and evaluation of the selected product or services in facilitating or blocking them to achieve their desired goals [9]. Consumer behaviour is highly influenced by different values perceived by the consumer themselves.

Past researchers have proved that perceived value is significantly affected by perceived benefits and perceived sacrifice. [10] and [11] have identified that perceived benefit had a positive effect on perceived value. Perceived benefit can also be seen as the perceived quality received or enjoyed when purchasing IoT Smart Homes. This study focused on the three sub-dimensions of perceived benefits, namely usefulness, enjoyment and facilitating conditions.

Usefulness is defined as the level of enhanced performance of the users after adopting new products or services, such as IoT Smart Home [12]. Enjoyment refers to the level of pleasure felt by the user after using new product or services [13]. Consumers are deemed to have favourable or likable emotions or attitude towards products that provide enjoyment to them. Facilitating Condition is the perceived organisational and technical infrastructure support received when adopting IoT smart home [14].

In terms of perceived sacrifice, [15] categorised perceived sacrifice in two categories, non-monetary sacrifice and monetary sacrifice. Innovative products or services, especially technological products and service is always bound to hidden and unexpected risk, thus causing consumers to postpone or avoid adoption to these items [16]. A total of four sub-dimensions of perceived sacrifice have been included in this study, which are privacy risk, technicality as well as innovation resistance.

Privacy Risk is one of the sacrifice made for the adoption or purchase of a connected technology system, such as an IoT Smart Home. It is defined as a concern for the administration of individual or group information and privacy via ICT products [17]. One of the most important issues in this information age is consumers' concerns about information privacy [18].

Next, technicality is also tested in this study to determine the level of difficulty to learn or use the new product and service like IoT Smart Homes [19].Innovation Resistance is defined as the negative attitude or emotion arose when customers faced with changes brought by the adoption of a new product or service [20].In addition, perceived fee is perception of consumers in regards of the fees required to purchase IoT smart home [21]. It is common that if the perceived price to purchase is too high, then the consumer's perceived value will be significantly affected.

The primary assumption in the consumers' decisions making process is the desire for value maximisation, where value considers and reflects both benefit and loss [8]. [20] identified that perceived value shows a positive relationship with adoption intention. Consumers usually exhibit a much favorable attitude and intention to adopt or purchase a new product or services when they have a higher perceived value about the product and services [23].

\section{Environmental Innovativeness and Concern}

Previous researches have shown that consumer' traits concerning environmental consciousness has a positive influence towards purchase intention, via either directly or other mediating effects. Environmental innovativeness is the consumers' level of openness in adopting environmental friendly products and services [5]. It also refers to the willingness of individuals to try an environmental innovative product or services [25]. 
[26] have reported that people are concerned about the environmental sustainability and willing to purchase items with innovative features that contribute to the environment. Next, environmental concern is referred as the awareness level of an individual towards environmental issues and their willingness to address it [4]. [26] found that the environmental concerns among Malaysians are increasing and these consumers are willing to spend on purchasing green products.

\section{METHODOLOGY}

The data collection method of this cross-sectional study was online self-administered survey. The targeted sample for this study was Malaysian above Twenty One (21) years old as the legal age for house purchase in Malaysia is 21 years old and above, according to Malaysian Law, Section 11 of the Contracts Act 1950. The sample size required by this study was 153 respondents, based on the analysis of $G^{*}$ Power Analysis, and the usable responses were 165.

A questionnaire was developed for data collection purpose. The questionnaire consisted of 6 parts, in which the first five sections were developed to examined the key variables of this study that measured by 5-point Likert scale. The last part of the questionnaire was designed to capture respondents' social demographic information such as age, gender, education background and monthly household income. SPSS was utilized to run data analysis to acquire a holistic and comprehensive understanding of the research findings.

\section{FINDINGS\& RESULTS}

Firstly, Frequency Analysis was performed on social-demographic items. Table 2shows that most them were female ( 99 respondents or $60.0 \%$ ), and 66 respondents $(40.0 \%)$ were male. In terms of age group, 114 respondents $(69.1 \%)$ were age 25 years old and below, and 51 respondents (30.9\% were aged above 25 years old.

For educational level, there were a total of 122 Bachelor's degree holders $(73.9 \%)$, followed by 26 respondents (15.8) who have obtained their postgraduate and professional accreditation, as well as 17 respondents $(10.3 \%)$ were High School graduates and below. Lastly, for household income, most of them earn below RM2,000 (91 respondents or $55.2 \%$ ), and same distribution for groups RM2,000-RM4,000 and above RM4,000, in which there were total of 37 respondents or $22.4 \%$, accordingly.

Table 2: Output of Frequency Analysis

\begin{tabular}{|c|c|c|c|}
\hline & Items & $\begin{array}{l}\text { Frequ } \\
\text { ency }\end{array}$ & $\begin{array}{c}\text { Percentage } \\
(\%)\end{array}$ \\
\hline \multirow[t]{2}{*}{ Gender } & Male & 66 & 40.0 \\
\hline & Female & 99 & 60.0 \\
\hline \multirow[t]{2}{*}{ Age } & $\begin{array}{l}25 \text { years old \& } \\
\text { below }\end{array}$ & 114 & 69.1 \\
\hline & Above 25 years old & 51 & 30.9 \\
\hline \multirow[t]{3}{*}{ Education } & $\begin{array}{l}\text { Postgraduate } \quad \& \\
\text { Professional }\end{array}$ & 26 & 15.8 \\
\hline & Bachelor's degree & 122 & 73.9 \\
\hline & $\begin{array}{l}\text { High school \& } \\
\text { below }\end{array}$ & 17 & 10.3 \\
\hline
\end{tabular}

\begin{tabular}{llll} 
Monthly & Below RM2,000 & 91 & 55.2 \\
Househol & RM2,000-RM4,000 & 37 & 22.4 \\
d Income & Above RM4,000 & 37 & 22.4 \\
\hline
\end{tabular}

Next, tests of different namely Independent t-test and one-way ANOVA were performed to test the differences between groups based on social-demographic profile. The outputs of analysis were presented from Table 3 until Table 6. Table 3 illustrated the results of analysis on gender.

The result of Independent t-test showed that males were significantly differently from females (4.06) on perceived fee with t-value of -2.275 , significant at .05 . However, no significant differences between male and female on perceived benefits, perceived usefulness, perceived enjoyment, perceived facilitating condition, perceived sacrifice, perceived privacy risk, perceived technicality, perceived innovation resistance, perceived value, environmental innovativeness, environmental concern as well as adoption intention on IoT Smart Homes.

Table 3: Output of Tests of Differences on Gender

\begin{tabular}{|c|c|c|c|}
\hline \multirow[t]{2}{*}{ Key Variables } & \multicolumn{2}{|c|}{ Mean } & \multirow[t]{2}{*}{$t$-value } \\
\hline & Male & Female & \\
\hline Perceived Benefits & 3.81 & 3.88 & -.717 \\
\hline Perceived Usefulness & 4.09 & 4.17 & -.770 \\
\hline Perceived Enjoyment & 3.89 & 4.13 & -1.927 \\
\hline $\begin{array}{l}\text { Perceived } \quad \text { Facilitating } \\
\text { Condition }\end{array}$ & 3.44 & 3.34 & .722 \\
\hline Perceived Sacrifice & 3.46 & 3.53 & -1.037 \\
\hline Perceived Privacy Risk & 3.65 & 3.59 & .518 \\
\hline Perceived Technicality & 3.58 & 3.70 & -1.162 \\
\hline $\begin{array}{l}\text { Perceived Innovation } \\
\text { Resistance }\end{array}$ & 2.85 & 2.77 & .946 \\
\hline Perceived Fee & 3.75 & 4.06 & $-2.275^{*}$ \\
\hline Perceived Value & 3.66 & 3.66 & .000 \\
\hline Environmental Innovativeness & 3.12 & 3.92 & 1.443 \\
\hline Environmental Concern & 3.97 & 3.82 & 1.312 \\
\hline Adoption Intention & 2.57 & 2.53 & .489 \\
\hline
\end{tabular}

Note: $*=$ sig. at $.05 ; * *=$ sig. at .001

Next, Table 4 presented the result of Independent t-test on age groups. For age, age group above 25 years old (4.09) showed significantly higher environmental concern, as compared to group 25 years old and below (3.78), with $\mathrm{t}$-value of -2.518 , significant at .05 . A similar finding was found on adoption intention too, in which age group above 25 years old (2.73) showed significantly higher adoption intention, as compared to group 25 years old and below (2.46), with t-value of -2.836 , significant at .05 .

Table 4: Output of Tests of Differences on Age Group

\begin{tabular}{llll}
\hline Key Variables & \multicolumn{2}{c}{ Mean } & \multirow{2}{*}{-value } \\
\cline { 2 - 3 } & $\begin{array}{l}\mathbf{2 5} \boldsymbol{\&} \\
\text { below }\end{array}$ & $\begin{array}{l}\text { Above } \\
\mathbf{2 5}\end{array}$ & \\
\hline Perceived Benefits & 3.85 & 3.86 & -.153 \\
Perceived Usefulness & 4.12 & 4.17 & -.439 \\
Perceived Enjoyment & 4.05 & 4.00 & .345
\end{tabular}




\section{A RESEARCH ON THE DIFFERENCES OF CONSUMERS ON SOCIO-DEMOGRAPHIC CHARACTERISTICS: THE INTERNET OF THINGS (IOT) SMART HOMES}

\begin{tabular}{llll}
$\begin{array}{l}\text { Perceived Facilitating } \\
\text { Condition }\end{array}$ & 3.37 & 3.41 & -3.15 \\
Perceived Sacrifice & & & \\
Perceived Privacy Risk & 3.49 & 3.51 & -.328 \\
Perceived Technicality & 3.61 & 3.62 & -.080 \\
Perceived Innovation & 3.65 & 3.65 & -.098 \\
Resistance & 2.77 & 2.89 & .699 \\
Perceived Fee & & & \\
Perceived Value & 3.95 & 3.90 & .314 \\
Environmental Innovativeness & 3.59 & 3.81 & -1.880 \\
Environmental Concern & 3.78 & 4.97 & .216 \\
Adoption Intention & 2.46 & 2.73 & $-2.518^{*}$ \\
\hline
\end{tabular}

Note: $*=$ sig. at $.05 ; * *=$ sig. at .001

In addition, one-way ANOVA analysis was performed on education level and monthly household income. One-way ANOVA was first performed in order to examine the significant differences between three different education levels, namely postgraduate and professional, Bachelor's degree, as well as high school and below. The results of analysis were presented in Table 5 .

Table 5: Output of Tests of Differences on Educational Level

\begin{tabular}{|c|c|c|c|c|}
\hline \multirow[t]{2}{*}{ Key Variables } & \multicolumn{3}{|c|}{ Mean } & \multirow{2}{*}{$\begin{array}{c}F- \\
\text { value }\end{array}$} \\
\hline & $\begin{array}{c}\text { Postgrad } \\
\text { uate \& } \\
\text { Professio } \\
\text { nal }\end{array}$ & $\begin{array}{c}\text { Bache } \\
\text { lor's } \\
\text { degre } \\
\text { e }\end{array}$ & $\begin{array}{c}\text { High } \\
\text { school } \\
\& \\
\text { below }\end{array}$ & \\
\hline Perceived Benefits & 3.97 & 3.82 & 3.88 & .543 \\
\hline $\begin{array}{l}\text { Perceived } \\
\text { Usefulness }\end{array}$ & 4.22 & 4.13 & 4.09 & .204 \\
\hline $\begin{array}{l}\text { Perceived } \\
\text { Enjoyment }\end{array}$ & 4.12 & 4.03 & 3.99 & .177 \\
\hline $\begin{array}{l}\text { Perceived } \\
\text { Facilitating } \\
\text { Condition }\end{array}$ & 3.58 & 3.56 & 3.31 & 1.433 \\
\hline $\begin{array}{l}\text { Perceived } \\
\text { Sacrifice }\end{array}$ & 3.57 & 3.49 & 3.43 & .601 \\
\hline $\begin{array}{l}\text { Perceived Privacy } \\
\text { Risk }\end{array}$ & 3.61 & 3.65 & 3.35 & 1.155 \\
\hline $\begin{array}{l}\text { Perceived } \\
\text { Technicality }\end{array}$ & 3.87 & 3.62 & 3.49 & 2.054 \\
\hline $\begin{array}{l}\text { Perceived } \\
\text { Innovation } \\
\text { Resistance }\end{array}$ & 2.72 & 2.77 & 3.15 & $3.920 *$ \\
\hline Perceived Fee & 4.10 & 3.93 & 3.74 & .929 \\
\hline Perceived Value & 3.91 & 3.59 & 3.75 & 2.536 \\
\hline $\begin{array}{l}\text { Environmental } \\
\text { Innovativeness }\end{array}$ & 3.09 & 3.98 & 2.98 & .175 \\
\hline $\begin{array}{l}\text { Environmental } \\
\text { Concern }\end{array}$ & 4.23 & 3.85 & 3.53 & $5.122 *$ \\
\hline Adoption Intention & 2.82 & 2.50 & 2.42 & $3.786^{*}$ \\
\hline
\end{tabular}

In terms of education level, significant results were found on perceived innovation resistance, environmental concern and adoption intention. The group of high school and below (3.15) showed significantly higher perceived innovation resistance as compared to the groups of Postgraduate and
Professional (2.82) and Bachelor's degree (2.77), with F-value of 3.920, significant at .05.

Apart of that, the groups of Postgraduate and Professional (4.23) and Bachelor's degree (3.85) were significantly different from the group of High School and below (3.53) on environmental concern, with F-value of 5.112, significant at .05. A significant result was also identified on perceived value, in which the group of Postgraduate and Professional (2.82) showed significant higher adoption intention as compared to Bachelor's degree group (2.50) and High School and below group (2.42), with F-value of 3.786, significant at .01 .

$$
\text { Note: } *=\text { sig. at } .05 ; * *=\text { sig. at } .001
$$

Lastly, in terms of monthly household income, significant results were found on environmental innovativeness and adoption intention. Basically low income group showed significant lower environmental concern and adoption intention. Table 6 showed the results of analysis of one-way ANOVA on monthly household income.

Table 6: Output of Tests of Differences on Monthly Household Income

Key Variables

$\begin{array}{cccc} & \text { Mean } & \boldsymbol{F} \text { - } \\ \text { value } & \text { RM2,0 } & \text { Above } & \text { value } \\ \text { RM2,0 } & 00- & \text { RM4,0 } & \end{array}$

\begin{tabular}{lcccc} 
& 00 & $\begin{array}{c}\text { RM4,0 } \\
00\end{array}$ & 00 & \\
\hline Perceived Benefits & 3.49 & 3.55 & 3.46 & 1.890 \\
Perceived Usefulness & 4.12 & 4.14 & 4.17 & .935 \\
Perceived Enjoyment & 4.10 & 3.97 & 3.93 & .792 \\
Perceived Facilitating & 3.38 & 3.49 & 3.28 & .589 \\
Condition & & & & \\
Perceived Sacrifice & 3.87 & 3.87 & 3.79 & .369 \\
Perceived Privacy & 3.58 & 3.73 & 3.57 & .599
\end{tabular}

Risk

$\begin{array}{lllll}\text { Perceived } & 3.65 & 3.60 & 3.70 & .248\end{array}$

Technicality

$\begin{array}{lllll}\text { Perceived Innovation } & 2.82 & 2.86 & 2.71 & .720\end{array}$

Resistance

$\begin{array}{lllll}\text { Perceived Fee } & 3.93 & 4.00 & 3.87 & .228\end{array}$

$\begin{array}{lllll}\text { Perceived Value } & 3.62 & 3.76 & 3.66 & .508\end{array}$

$\begin{array}{lllll}\text { Environmental } & 3.68 & 4.11 & 4.14 & 5.112 *\end{array}$

Innovativeness

$\begin{array}{lllll}\text { Environmental } & 3.68 & 4.11 & 4.14 & 7.875\end{array}$

Concern

$\begin{array}{lllll}\text { Adoption Intention } & 2.41 & 2.68 & 2.74 & 6.006^{*}\end{array}$

Note: $*=$ sig. at $.05 ; * *=$ sig. at .001

Based on the research findings, the group with monthly household income below RM2,000 (3.68) showed significant lower environmental concern as compared to groups of RM2,000-RM4,000 (4.11) and above RM4,000 (4.14) with F-value of 7.875, significant at .01. A similar research finding was found on adoption intention, in which the group with monthly household income below RM2,000 (2.41) showed 
significant lower environmental concern as compared to groups of RM2,000-RM4,000 (2.68) and above RM4,000 (2.74) with F-value of 7.875, significant at .01.

\section{DISCUSSIONS\& RESULTS}

Due to the projected research and development in the IoT, this research has examined the important variables under the Value-based Adoption Model, namely perceived benefits, perceived sacrifice, perceived value and adoption intention, particularly the sub-dimensions of perceived benefit and sacrifice. Beyond the key variables under the Value-based Adoption model, this study also covered environmental innovativeness and environmental concern. The results of the tests of difference are interested, in which significant results were found for all the studied social-demographic items.

Males were found to show significantly lower perceived fee of IoT Smart Homes than females; while group above 25 years old tended to show greater environmental innovativeness and adoption intention. In addition, higher educated groups showed significantly lower perceived innovative resistance, as compared to the low educated group. Also, both higher educated and household income groups displayed significantly greater environmental concern and adoption intention.

The research findings shed light to both government and market practitioners. Males, older age group, as well as higher educated and household income groups displayed more positive attitudes towards IoT Smart Homes. Government and market practitioners are encouraged to target their awareness and promotional campaigns to these groups of customers.

\section{LIMITATIONS and FUTURE RECOMMENDATIONS}

First, this study was suffered with the scope in which focuses solely on socio-demographic profiles of respondents, namely gender, age group, educational level, and monthly household income. Hence, future researchers are encouraged to expand this study by examining consumers' psychographic variables, such as lifestyle, need for cognition, and worldmindedness. Future researchers are also welcomed to replicate this study and examine it in the context of different country and industry.

Secondly, this study examined only the differences of consumers based on the key variables in the Value-based Adoption Model. As the focus of Value-based Adoption Model is on consumers' adoption intention and the associated factors, hence the contributions of the study might be constrained. Therefore, future researchers are also encouraged to conduct study on preliminary stage, such as examining consumers' awareness, knowledge level and acceptance level on IoT Smart Homes.

Apart of that, they can also consider exploring the source of information on the relevant topics, hence this will provide more comprehensive insights to both policy makers and market practitioners. Market practitioners will be greatly benefited from the potential research outcomes, and would be able to design marketing programme and develop product that better cater the needs and wants of their potential customers.
Apart of that, future researchers are also encouraged to extend this study by examining the actual purchase decision of customers. For instance, they shall consider exploring the decision making process and the associated factors that affecting their purchase decision. Also, they could also study customers' intention to recommend, word of mouth, and their loyalty level. The results of the associated studies would able to help market practitioners in cater a more personalised customer relationship management programme to their existing customers.

\section{REFERENCES}

1. T. Stock and G. Seliger, "Opportunities of Sustainable Manufacturing in Industry 4.0", Procedia CTRP, pp. 536-541, 2016.

2. K. Ashton, "That 'Internet of Things' Thing", RFID Journal,

<https://www.rfidjournal.com/articles/view?4986>, 1999 , viewed on 30th December 2018

3. S. A. Chua, "Cover Story: The state of IoT in Malaysia," <http://www.theedgemarkets.com/article/cover-story-stat e-iot-malaysia>, viewed on 30th December 2018, 2017.

4. M. F. A. Zaidi, "The IoT Readiness of SMEs in Malaysia: Are they Worthwhile for Investigation?", International Conference on International Business, Marketing and Humanities, 2017.

5. Y. Kim, Y. Park, and J.Choi, , "A study on the adoption of IoT smart home service: using Value-based Adoption Model", Total Quality Management \& Business Excellence, 2017.

6. H.-W. Kim, H.C. Chan and S. Gupta, "Value-based Adoption of Mobile Internet: An empirical investigation", Decision Support Systems, pp. 111-126, 2007.

7. T.-C. Lin, S. Wu, J. S.-C. Hsu and Y.-C. Chou, "The integration of Value-based Adoption and Expectation-Confirmation Models: An example of IPTV continuance intention", vol. 53 (2), pp. 63-75, 2012.

8. D. Kahneman, and A. Tversky, "Prospect Theory: An Analysis of Decision under Risk", Econometrica, vol. 47(2), pp. 263-291, 1979.

9. R. B. Woodruff, "Customer value: The next source for competitive advantage", Journal of the Academy of Marketing Science, vol. 25, pp. 139, 1997.

10. R. K. Teas, and R. Argawal, "The Effects of Extrinsic Product Cues on Consumers' Perceptions of Quality, Sacrifice, and Value", Journal of the Academy of Marketing Science, vol. 28(2), pp. 278-290, 2000.

11. B. Lin, W. M. Teoh, S. C. Chong, and J. W. Chua, "Factors affecting consumers' perception of electronic payment: an empirical analysis", Internet Research, vol. 23(4), pp. 465-485, 2013.

12. R. Cheung, and D. Vogel, "Predicting user acceptance of collaborative technologies: An extension of the technology acceptance model for e-learning", Computers \& Education, vol. 63, pp. 160-175, 2013.

13. Reychav, and D. Wu, "Mobile collaborative learning: The role of individual learning in groups through text and video content delivery in tablets", Computers in Human Behavior, vol. 50, pp. 520-534, 2015.

14. V. Venkatesh, J. Y. L. Thong, and X. Xu, "Consumer Acceptance and Use of Information Technology: Extending The Unified Theory of Acceptance and Use of Technology", MIS Quarterly, vol. 36(1), pp. 157-178, 2012. 

THE INTERNET OF THINGS (IOT) SMART HOMES

15. V. A. Zeithaml, "Consumer perceptions of price, quality, and value: A means-end model and synthesis of evidence", The Journal of Marketing, vol. 52, pp. 2-22., 1988.

16. A. Dhebar, "Information technology and product policy: 'Smart' products", European Management Journal, vol. 14(5), pp. 477-485, 1996.

17. A. M. Angst, and R. Agarwal, "Adoption of Electronic Health Records in the Presence of Privacy Concerns: The Elaboration Likelihood Model and Individual Persuasion”, MIS Quarterly, vol. 33(2), pp. 339-370, 2009.

18. E. M. Caudill, and P. E. Murphy, "Consumer Online Privacy: Legal and Ethical Issues", Journal of Public Policy \& Marketing, vol. 19(1), pp. 7-19, 2000.

19. W. H. DeLone, and E. R. McLean, "Information Systems Success: The Quest for the Dependent Variable", Journal of Management Information Systems, vol. 3(4), pp. 60-95, 1992.

20. S. Oreg, "Personality, context, and resistance to organizational change", European Journal of Work and Organisational Psychology, vol. 15(1), pp. 73-101, 2006.

21. H. Y. Wang, and S. H. Wang "Predicting mobile hotel reservation adoption: Insight from a perceived value standpoint", International Journal of Hospitality Management, vol. 29, pp. 598-608, 2010.

22. O. Turel, A. Serenko, and N. Bontis, "User acceptance of hedonic digital artifacts: A theory of consumption values perspective", Information \& Management, vol. 47, pp. 53-59, 2010.

23. M. K. Kim, O. Jeesun, J. H. Park and C. Joo, "Perceived value and adoption intention for electric vehicles in Korea: Moderating effects of environmental traits and government supports", Energy, vol. 159, pp. 799-809, 2018.

24. M. Ahn, J. Kang, and G. Hustvedt, "A model of sustainable household technology acceptance", International Journal of Consumer Studies, vol. 40, pp. 83-91, 2016.

25. Arnold, "More Millennials Are Becoming Homeowners, But Do They Want Smart Homes?", $<$ https://www.forbes.com/sites/andrewarnold/2 018/05/28/more-millennials-are-becoming-homeownersbut-do-they-want-smart-homes/\#4d7f028d38f8>， 2018, viewed on 30th December 2018.

26. N. MohdSuki, "Consumer environmental concern and green product purchase in Malaysia: structural effects of consumption values", Journal of Cleaner Production, Vol. 132, pp. 204-214, 2016.

\section{AUTHORS PROFILE}

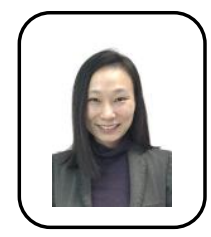

Dr. TeoPohChuinis a Senior Lecturer in AzmanHashim International Business School, UniversitiTeknologi Malaysia. She obtained her Doctor of Philosophy from UniversitiSains Malaysia. She worked as a Business Development Manager in Singapore, particularly focus on international trading and wholesaling. Apart of that, she has also served as a Senior Lecturer at Tunku Abdul Rahman University College. Her research interests include brand's country of origin, the Internet of Things and Belt \& Road Initiative. She is familiar with mixed-method research design, and she is experienced in leading research centre and research grant. Her research outputs have been presented in international conferences, as well as published in international journals and books.

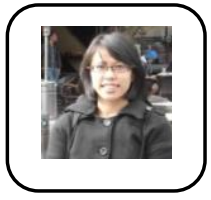

Dr. Theresa Ho is a Senior Lecturer at AzmanHashim International Business School, UniversitiTeknologi Malaysia, Kuala Lumpur. Her area of research includes Strategic Management, Intellectual Capital, Entrepreneurship, Small and Medium Enterprises (SMEs) and OrganisationalBehaviour. She has published 18 articles in reputable journals and conference proceedings such as Journal of Asia Pacific Business, International Journal of Innovation Science and Journal of Relationship Marketing. She specialises in Structural Equation Modeling (SEM).

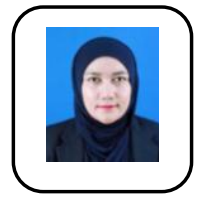

Dr. Rafidah Othman is a senior lecturer at AzmanHashim International Business School Malaysian University of Technology with a specialization in Finance, Banking, Investment and Global Business Strategy. She granted her PhD in Finance and Master in Business Administration majoring in Applied Finance and Investment from UniversitiKebangsaan Malaysia, While her Bachelor in Business Administration (Hons) (Finance) from UniversitiTeknologi Mara. She has a long service history in banking industry ranging from Bank SimpananNasional (1988 - 2006) and Citibank (M) Berhad (2006 - 2009). After serving 22 years in banking line, she decided to endeavor into academic world by joining UniversitiTenagaNasional as a Lecturer in 2009 and Infrastructure University Kuala Lumpur from 2011 to 2018 . Her specialization and research area is in Investment, Behaviorial Finance Banking and Corporate Finance. With her broad experience she envisages on bridging the gaps between theory and practical and visualizes collaboration between academic and industries in order to bring Malaysian financial industry to a highest level.

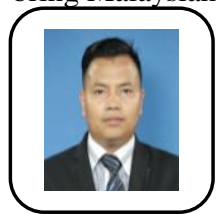

Dr. BeniWidarmanYusKelana is a Senior Lecturer at AzmanHashim International Business School, UniversitiTeknologi Malaysia, Kuala Lumpur. His research areas include Human Resources Development, Human Resources Sustainability, Organizational Behavior, Continued Professional Development and Small Medium Enterprise (SMEs). He holds a PhD in Management and Master in Human Resources Development from University Teknologi Malaysia. He has experiences in managing Human Resources activities at Security Department, UniversitiTeknologi Malaysia. After eight years as an administrator, he decided to endeavor into academic world by joining Universiti Utara Malaysia as a Senior Lecturer in 2018 and UniversitiTeknologi Malaysia from 2019 until now.

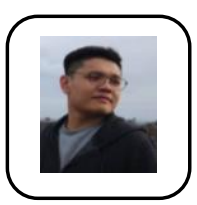

Mr. Daniel Tie works as a manager in a firm in industry. He obtained his Master of Business Administration degree from Tunku Abdul Rahman University College. 